\title{
The Investigation into Determinants of Regional Exports Base: Panel Analysis for Spanish and Polish Regions
}

\author{
Tomasz Brodzicki, Laura Márquez-Ramos, Stanisław Umiński
}

\begin{abstract}
A B S T R A C T
Objective: We use the small open economy concept to identify the determinants of region's exports at a NUTS-2 level for Poland and Spain over the period 2005-2015.

Research Design \& Methods: We apply the Prais-Winsten method for Panel Corrected Standard Errors (PCSE) on a data panel allowing for heteroskedasticity and autocorrelation estimating a model of regional exports for a joint sample of Polish and Spanish NUTS-2 regions.

Findings: We identify a number of factors which statistically significantly determine exports arising from Polish and Spanish regions. These factors are classified into the following main groups: factor conditions, FDI, infrastructure, market conditions, remoteness and geography, spatial agglomeration and technological knowledge base.

Implications \& Recommendations: By going beyond national trade statistics, we provide evidence which can be used at the regional level to increase participation of regions in the world economy. Political decisions which are taken at the regional level seem to matter.
\end{abstract}

Contribution \& Value Added: This paper combines scientific knowledge from several perspectives: international economics and international business, as well as regional science. We believe that an interdisciplinary approach is necessary to increase the knowledge which goes beyond nations, while not focusing on firms, as units of analysis.

\begin{tabular}{ll}
\hline Article type: & research paper \\
Keywords: & exports; region; Poland; Spain; panel-data; PCSE; determinants \\
JEL codes: & R11, F14, C23
\end{tabular}

Received: 3 December $2017 \quad$ Revised: 7 February 2018 Accepted: 23 February 2018

Suggested citation:

Brodzicki T., Márquez-Ramos, L., \& Umiński, S. (2018). The Investigation into Determinants of Regional Exports Base: Panel Analysis for Spanish and Polish Regions. Entrepreneurial Business and Economics Review, 6(1), 135-151. https://doi.org/10.15678/EBER.2018.060108 


\section{INTRODUCTION}

The interest in the regional perspective of exporting has grown over the years. Data on exports of enterprises established in regions within countries (i.e. subnational units) have gradually become more available. Regional authorities show more interest in their export potential because globalisation makes the regional economies more open and vulnerable to external economic shocks. The international trade channel has become an important factor influencing a region's economic performance, including the dynamics and volatility of economic growth as well as the labour market performance. Due to the economic transition and the accession to the European Union (EU), Poland's regions have become more open than ever. For regions of both Poland and Spain (an EU country similar to Poland in terms of the size and number of administrative units), being part of the EU's internal market with free circulation of goods and capital - exerts competitive pressure that can be regarded a stress test, showing the regional adaptive capacity and competitiveness.

Regions differ in many aspects, including size, the structure of the economy, the overall level of development, human as well as physical capital endowment, attractiveness to investors, transport infrastructure, proximity to foreign markets, etc. Foreign trade activity is another sphere in which regional disparities can be observed, which so far has often been neglected (Umiński, 2016).

We focus on identifying factors which determine the so-called export base of regions. This question has not been thoroughly tackled in the empirical literature. If determinants of region's foreign trade relations are investigated, they are mostly analysed with the use of a gravity approach (Brodzicki \& Umiński, 2018; Márquez-Ramos, 2016b). The gravity concept offers many advantages and gravity related models, in fact, they have become the main tool of analysis of the intensity of bilateral trade relations. However, their major disadvantage is often the limited availability of data in a region-country framework. This disadvantage makes the identification of many interesting factors affecting trade difficult. On the other hand, the availability of data for individual regions is notably greater.

We investigate empirically the determinants of the regional export base using panel data models. We do it for regions from two EU Member States - Poland and Spain. Both countries are relatively large member states of the EU, situated on its peripheries. Each of them is bordering a 'big neighbour', which for Spain is France and for Poland - Germany. The neighbour is the main partner in foreign trade. In addition, Spain and Poland are at the roughly similar level of development. Both countries did not belong to the founding six member states of the European Economic Community (EEC), as they joined the EU later. Both underwent a transition from dictatorship to democracy, they are similar in size and population, as well as in the number of NUTS-2 regions (16 in Poland, 19 in Spain). Despite the similarities, there are important differences between them. Poland is currently not a member of the eurozone (it enjoys temporary derogation). Both countries differ from an institutional point of view. The two-country perspective helps to identify more universal rules regarding the determinants of exports, therefore allowing to draw more robust conclusions. On the other hand, the differences between the two countries can also be traced. Altogether 35 NUTS- 2 regions are analysed which represent a large research object. The analysis covers the period 2005-2015. 
We contribute to the body of the literature by using regions from a two-country perspective, which makes our results and observations more universal than for one country case, as exports for regions is usually assessed. We use the statistical data which are not simulated/estimated (as is often the case in similar research), which allows our research to reflect the nature of regions' exports better. Furthermore, we contribute to previous knowledge on the determinants of the regional export base, including a number of factors which have been typically neglected. Last but not least, by identifying export-affecting factors, we provide important information for decision makers responsible for export promotion at the regional level.

We utilize data from a number of sources: Polish Customs Chamber (Izba Celna) and DataComex Español, the Quality of Government EU Regional Dataset (Charron et al., 2016) and from Polska Agencja Informacji i Inwestycji Zagranicznych (PAlilZ), as well as the Spanish Ministry of Economy and Competitiveness. We also utilize Penn World Tables PWT 9.0. (Feenstra, Inklaar, \& Timmer 2015).

The remainder of the paper is structured as follows. Section two reviews theoretical and empirical analyses on the discussed topic. Section three presents the dataset, reviews the data sources and presents our empirical strategy and methods of econometric estimation. Section four presents the results. The last section discusses the key results and concludes.

\section{LITERATURE OVREVIEW}

Essentially, we refer to the economic base theory as an underlying concept which links regions to the external economy. The economic base concept is predominantly understood as a method of analysis which divides the region's economy into the output consumed outside it and the one absorbed internally (Sirkin, 1959). Initially, no particular attention was paid to whether the external sector means a foreign one, or not (North, 1955). Our interpretation of the export base model is in terms of 'foreign' exports; factors stimulating the exports of a region are of the supply-side nature, however, the discussion about the supply and demand aspects of the export base model is on-going in the literature (Ha \& Swales, 2012).

International economics provides many theoretical concepts which explain trade. Their application to the regional scope of analysis is, however, limited. For a long time, economists have been treating countries as if regions did not exist. Export flows come from an undefined, homogenous space, which is in contrast with the reality in which countries are internally diversified in many respects. They are lumpy (Brakman \& van Marrewijk, 2013; Courant \& Deardorff, 1992), which manifests in differentiated factor endowments, the economic structure and thus production, employment and product profiles, proximity to foreign markets, transport infrastructure as well as human capital availability. The consequence of unevenness is the differentiation of the regional export base that determines the ability of a given region to participate in the external economy.

The new-new theory of international trade allows firms to differ (Mayer \& Ottaviano, 2008; Melitz, 2003). The firm-level asymmetry is revealed in the fact that only some firms export, once they reach the necessary productivity threshold. Heterogeneity manifests in other aspects of firms' activity and embraces their innovative capacity. In addition, firms' endogenous location decisions matter. The regional portfolio of firms thus has to be taken into account as one of the key determinants of regions' exports. The most competitive 
regions attract the bulk of the most competitive firms, which is reflected in the agglomeration processes around metropolises (Parr, Hewings, Sohn, \& Nazara, 2002).

Foreign ownership can be treated as another aspect of firms' heterogeneity. Foreignowned entities (FOEs) possess ownership, localisation and internalisation advantages which contribute to their superior market performance. They fulfil functions described by Forsgren (2008) as dominators, coordinators, knowing firms (creating values), designers, networkers or politicising multinationals. Their influence on the regional economic performance is supposed to be positive for both Spanish and Polish regions, although the MNE are named by Forsgren (2008) 'a beauty and a beast', which relates to both positive and adverse consequences of their activity. Their impact on regional exports depends also on the structure of incentives which drive the FOEs activity, which can be a market, resources, efficiency and strategic assets and capabilities seeking (Dunning \& Lundan, 2008). Also, the character of the multinational structure matters, as it determines the position and functions performed by a particular firm within the MNE (Estrin, Meyer, Wright, \& Foliano, 2008). At a more aggregated level, the nexus between foreign direct investment (FDI) and regional exports is more complex, with a number of factors playing a role, such as the vertical or horizontal nature of the FDI or the structure of the regional economy affecting the absorptive capacity. These factors have been analysed both for Spain (e.g., Rodriguez \& Pallas, 2008; Villaverde \& Maza, 2012), as well as for Poland (e.g. Gradzewicz \& Kolasa, 2005; Kolasa, 2008, Cieślik, 2017a, 2017b) in the hereto literature of the subject, but not in the direct context of the present study. Taking all factors into account and remembering the nuances, we expect the FDI to play a significant and overall positive role in determining the regional export base.

A theory which brings together localisation issues, agglomeration and international trade is New Economic Geography (NEG). The concept of heterogeneity is implemented to NEG models (Baldwin \& Okubo, 2005; Ottaviano, 2011), which makes them more realistic also through reducing the chances of the so-called catastrophic agglomeration. NEG seems to be the proper framework for the analysis of regions' exports determinants. Spanish and Polish regions are the EU member states, witnessing falling trade costs and pursuing enhanced integration within the EU's internal market. Within both countries, the regions are different, some of them are peripheral, while others are more central. The peripherality (or 'centrality') is further induced by the activity of FOEs, which tend to agglomerate predominantly in the most competitive regions.

As a conceptual framework alternative to NEG, Evolutionary Economic Geography (EEG) ought to be mentioned (Boschma, 2005; Boschma \& Frenken, 2011). It puts a strong emphasis on path dependency, institutional quality, related variety and regional spin-offs.

The research focused on determinants of exporting activity at the regional level is not affluent. Naudé and Gries (2009) paid attention to the role of geography and relative factor endowment. The following main determinants of regional exports have been identified: the economic size of a region (the home market effect), better access to foreign markets, low transport costs, high quality of local institutions and high skills to labour ratio. In another study for South Africa, Matthee and Naudé (2008) conclude that in the case of a developing country's regions, the distance to the nearest port is a more important determinant, compared to the European regions' case. 
Nicolini (2003) used a 'beyond gravity' approach in the assessment of the export potential of six European regions, focusing on the importance of transport costs and the home market effect. Berube and Parilla (2012) argue that metropolitan areas are essential for international trade. In the global economy, cities return to the role they traditionally used to play - as major commercial nodes in international trade. Also, Guerrieri and lammarino (2006) have found for Italian regions that significant export capacity is accompanied by regional clustering and the so-called contextual dynamism related to the high standard of living.

Simmie (2002) argues that the export base theory seems to be a seriously revisited theory explaining the nexus between regional competitiveness, regions' exports and clustering of economic activity. Simmie (2003) identifies urban regions as international nodes of sharing and transferring knowledge, which generate competitiveness and exports. A similar conclusion has been formulated by Becchetti, Panizza and Oropallo (2007). Firms located in industrial districts export more than firms located elsewhere and there are selfreinforcing relationships between productivity and growth, stimulating exports.

Andersson and Johansson (2010) have shown that regions' endowment in human capital influences the structure of exports. This is the extensive trade margin that is predominantly affected by diverse endowments in human capital. Larger municipalities in Sweden have higher volumes of exports. Johansson and Karlsson (2007) prove that accessibility to R\&D (for Swedish regions) positively influences the number of exported products, exporting firms and destinations.

The question of countries' internal lumpiness has been inquired by Brakman and van Marrewijk (2013), who conclude that the lumpy distribution of production factors and urbanisation could exert influence on trade patterns and make them differ from the predictions of Heckscher-Ohlin model. Cassey (2011) confirms that exports are highly concentrated regionally and border regions export more than interior ones.

Wahl (2016) has shown the consequences of the existence of historical trade centres and contemporary development that are transmitted through agglomeration processes, which in the light of the research on regions' exports brings important conclusions about the role of historical factors. Pradhan and Zohair (2016) have identified spatial differences that influence heterogeneity in the exports performance of regions.

As far as the role of FDI is concerned, Sun (2001) concludes that the FDI impact on the exports of Chinese regions differs. For coastal regions it is stronger than for inland ones, while for western regions it is insignificant. It is not surprising, taking into account the complex relations between FDI, exports, imports and regional growth.

Ciżkowicz, Rzońca and Umiński (2013) have found that regional export performance in Poland is positively influenced by the labour productivity, the share of foreign-owned enterprises in employment, regions' educational characteristics and location at the border of the country. Brodzicki and Umiński (2018) in the analysis of the panel model for the exports of Poland's regions pointed the role of municipalities, as well as of the historical legacy.

The above-presented literature proves that different determinants have been used in the inquiry into the exports of regions. Pradhan and Das (2015) have conceptualised regional export competitiveness factors, which influence exports, into the following groups: market conditions, factor conditions, spatial agglomeration, FDI and technological knowledge base. Márquez-Ramos (2016a) in a study of international trade of Spanish regions distinguished 
three components of the institutional environment (international, supranational and a subnational context). Within the subnational context, the following region's (exports origin) characteristics are distinguished: income, income per capita, remoteness and geography and infrastructure. The list of explanatory variables in the present study, together with their definitions and predicted impact on the dependent variable, is provided in Table 1. Following Pradhan and Das (2015) and Márquez-Ramos (2016a), they are grouped into the following categories: factor conditions, FDI, infrastructure, market conditions, remoteness and geography, spatial agglomeration and technological knowledge base.

\section{MATERIAL AND METHODS}

The data panel which we use was constructed for 16 NUTS-2 level regions of Poland (voivodships) and 19 NUTS-2 level regions of Spain (17 autonomous communities and 2 autonomous cities) over the period of 2005-2015. This gives a total of 385 observations. Due to missing data in some of the specifications considered, the number of observations falls to 340 . The data were acquired from a number of sources. The data on exports for Polish and Spanish regions were obtained from the Polish Customs Chamber (Izba Celna) and DataComex Español database (http://datacomex.comercio.es). The log of the value of region's exports is our dependent variable. The data for regions were predominantly acquired from the Quality of Government EU Regional Dataset (Charron et al., 2016). The data on FDI inflows by trade partner into regions were obtained for Poland from PAlilZ (currently Polska Agencja Inwestycji i Handlu - PAlH) and from http://datainvex.comercio.es, as well as from the Spanish Ministry of Economy and Competitiveness for Spain.

The data on regional total factor productivity (TFP) were obtained in the following way. We utilized the Penn World Tables PWT 9.0. country-level TFP yearly estimates for Poland and Spain and then we approximated the regional TFP using the ratio of regional real GDP per capita to the national mean. The observed variation in income per capita is mostly driven by differences in TFP (Easterly \& Levine, 2001) and thus TFP is generally considered the prime determinant of regional real GDP per capita. TFP differences are substantial between regions from different countries, as well as between regions within countries and to large extent can be attributed to discrepancies in economic geography and historical development paths (Beugelsdijk, Klasing, \& Milionis, 2017). The estimation of TFP at the regional or subregional levels encounters a number of problems (Ciołek \& Brodzicki, 2016). The method applied, despite a potential bias, allows us to be coherent with the TFP estimates at the level of countries.

The dummy variables for the border region, the access to sea or capital region are the result of own elaboration. In order to account for the metropolitan status of a region, we took the ESPON study (Dühr, 2005) on metropolitan areas in the European Union and constructed a dummy variable for metropolitan regions (metro), and in addition we took into account the MEGA classification thus creating dummy variables for MEGA 1, 2, 3 \& 4 regions (mega1, mega2, mega3 \& mega4). In the case of the Spanish or Polish regions, MEGA 2 does not occur. The descriptive statistics of the utilized variables, their definitions and sources are given in Table 1.

The empirical strategy in the present article is the following. We construct a basic specification of the model of regional exports and then extend it to test a number of hypotheses. The analysis is conducted jointly for a sample of Polish and Spanish NUTS- 
2 regions. We checked the robustness of the results by splitting the sample of the regions into two national subsamples - it does not affect the key results. The addition of the fixed temporal effect does not significantly affect the results, either (the estimates will be made available upon request).

The selection of the method of estimation method was made on the basis of the review of empirical literature on the subject undertaken and upon investigation of the data in our two-country regional panel data sample. Several possible estimation methods were investigated. For instance, Ciżkowicz et al. (2013) in their empirical analysis for Polish regional exports utilized four approaches: standard pooled type estimator (OLS), Panel Corrected Standard Errors (PCSE) on a panel of data, PCSE - AR - allowing for heteroskedasticity and autocorrelation in panels and finally generalised least squares (GLS) - assuming the autocorrelation coefficient is fixed for the whole panel.

In the case of our study, we deal with regions of Poland and Spain considered jointly. Thus, heteroskedasticity could be an obvious problem. We first estimate the base specification of the model (M1) on pooled data using OLS estimator. Then in the postestimation phase, we apply the Cook-Weisberg test for heteroskedasticity (hettest). The value of the chi2(1) test (263.46) points to a rejection of the null hypothesis of constant variance. Therefore, as expected we deal with heteroskedasticity. Furthermore, the analysis shows that we deal with autocorrelation and that it differs between the regions considered. Therefore, we adopt PCSE-PSAR1, that is Prais-Winsten regression, with correlated panels corrected standard errors (PCSEs). Beck and Katz (1995) have shown that in this case PraisWinsten estimates with PCSEs is superior to FGLS estimates.

In order to identify the differences clearly, we present each specification of the model twice. Firstly, it is estimated on pooled data with OLS assuming homoskedasticity and lack of autocorrelation. And, secondly, on panel data using Prais-Winsten estimator with PCSEs allowing for actual heteroskedasticity and the region-specific autocorrelation process. Our interpretation is based on the second approach. The estimates are provided in Table 2.

\section{RESULTS AND DISCUSSION}

Several specifications of the model were tested with the use of different estimation methods in accordance with our empirical strategy described above. The baseline specifications are $\mathrm{M} 1$ and $\mathrm{M} 2$. M1 presents the estimates of the pooled OLS model and M2 of the preferred method - PCSE-PSAR1, allowing for heteroskedasticity and region-specific autoregressive process. The results obtained are in line with our expectations (Table 1, column 'expected sign' and Table 2). Furthermore, PCSE-PSAR1 estimation method brings the highest goodness of fit. As it could be expected, both methods give slightly different magnitudes impact of the independent variables on the value of exports.

A way of validating the results is to observe whether they are robust for the different specifications. Looking at all specifications considered (M1 - M16), the basic factors taken into account, in most of the cases, are statistically significant and their impact on the dependent variable is in line with theoretical expectations. The impact of a region size, as measured by the log of its total population, is positive. This is in line with Nicolini (2003) and the concept of the home market effect, fundamental to NEG theories. Among factors, also the size of the region in terms of its area in square $\mathrm{km}$ has a positive impact. The share 
of agriculture in regional employments exerts a negative impact and the share of manufacturing in total employment a positive impact - on the value of a region's exports. It is in line with the expectations. Looking from that perspective, deindustrialisation could be considered a major threat to a region's export base. The reindustrialisation postulate, pursed at the EU level, implemented in Poland - would thereof positively influence the regional export base. On the other hand, in the case of less developed regions, these are agricultural products that represent an important share of exports. Having comparative advantages related to food and agricultural products can also constitute good prospects for exports, especially if marketing capabilities and human capital (necessary to successfully penetrate foreign markets) will be improved. At the same time, more developed regions - as shown by the log of their real GDP per capita - ceteris paribus, export more. Among the other basic factors, their impact is generally positive - border regions show superior export performance, direct access to the sea proves beneficial and finally, this applies to the metropolitan status of a region (metro).

In the M3 and M4 specifications, we controlled for geographical/remoteness variables which are the longitude and the latitude of a region's capital city, of which only the latter has a significant (and positive) impact on the dependent variable. The latitude of the capital city of the region in the literature is treated as the one, which reflects the climate characteristics. In fact, little is known about the influence of latitude on exports; however, some correlation can be seen with agglomeration propensity. For instance, Chasco, Lopez and Guillain (2012) have found lower latitude to be negatively correlated with economic agglomeration in a panel of European NUTS-2 regions. Our results are in line with this observation. The introduction of latitude (which turned to be significant and which positively influences exports) eliminated the significance of the variable metro. Thus, the variable latitude took over the influence of variable metro.

At the same time, greater longitude (more easterly location) exerts a negative impact on the value of regional exports. We argue that this could reflect the impact of more peripheral location in Europe.

In the next specifications (M5-M6), the FDI factor was included, as the cumulated number of FOEs in a region. With high statistical significance, it positively affects the value of regional exports. The inclusion of this variable reveals the export- creating nature of FOEs, however, a higher magnitude was expected. The nature of FOEs is probably of large bearing, and it should be a matter of further research - if more precise data on FOEs would be available. It would be, for instance, interesting to inquire into the distribution of FOEs by size, as these are the largest of them (that are MNEs) which are able to fulfil functions described by Forsgren (2008). Smaller FOEs are not able to positively contribute to exports, in comparison to 'big' multinationals. The obtained results show the export-creating nature of FDI. However, in order to robustly prove the complementarity between trade and FDI, information on the impact of the share of FOEs in the regions' exports would be recommended to include in the model. Unfortunately, this kind of information is not available for Spain.

The inclusion of the number of FOEs reduced the magnitude of influence exerted by the population size (with the PCSE-PSAR1 method) and resulted in the increased magnitude of the metropolitan dummy. This reflects the role of metropolises as the nodes of globalisation. Metropolises also attract the bulk of the FOEs. We expect the increasing role of the metropolitan areas as a factor determining regional exports. Exporting is 
a difficult activity, requiring human capital capabilities, as well as sharing, matching and learning. The proximity to other exporters which cluster in and around metropolises, positively affects spillover effects (Duranton \& Puga, 2004).

In the next specification, we look closer at the status of the region (M7-M8). It is clear from the obtained results that capital regions, ceteris paribus, export more. We furthermore differentiate between the significance of the metropolitan centre of the region by applying the ESPON'S MEGA classification. It seems that the impact of MEGA1 and MEGA4 is significant. The impact of MEGA 3 is positive but insignificant. This could be the effect of Mazowieckie (with Warsaw), being the capital region of Poland (which is not the case with Madrid, classified as MEGA1).

In M9-M10 we control for region's TFP. In this specification, the real GDP per capita is omitted due to co-linearity reasons. The impact of TFP on the regional exports is positive and statistically significant. More productive regions, ceteris paribus, export significantly more. This is in line with both our expectations and the predictions of the firms' heterogeneity concept by Melitz (2003).

In M11-M12 we control for a region's innovative potential. We do it, firstly, by accounting for the human capital endowment. Its impact on the regional exports is found to be insignificant, which is at least surprising. Secondly, contrary to our expectations, and to the predictions of the heterogeneous firms' concept, the impact of business expenditures on R\&D as a percentage of real GDP of a region is not statistically significant.

In the last specifications (M13-M16), we control for transport infrastructure endowment of the region (the estimated coefficients are expected to be positive, see Table 1 and, for example, Bensassi, Márquez-Ramos, Martínez-Zarzoso and Suárez-Burguet, 2015). In M15-M16 we omit the impact of direct access to the sea, to be able to verify the effect of a seaport (as shown by the size of maritime transport). The impact of railways is positive and statistically significant. The impact of motorways is positive, however, significant only at $10 \%$ level. The impact of other roads, ceteris paribus, is negative and insignificant or significant only at $10 \%$ level. Surprisingly, the impact of maritime transport (as a measure of a seaport size) is adverse and statistically significant in M14. It becomes insignificant if the impact of the location at the seaside is excluded. The result could be related to the significance of road transport in the intra-European trade, which in turn plays a dominant role in trade relations of the analysed regions. Finally, the impact of the airport (as shown by airport freight size) is statistically insignificant.

\section{CONCLUSIONS}

Taking into consideration that regions perform many important functions, we pay attention to an often-neglected one, which is international trade. The focus on regional determinants of exports rests on the general assumption that regions can be treated as small open economies. This enables to make use of a number of theoretical and empirical approaches which are used in international economics. The research presented has important policy implications, as regions are becoming increasingly interested in the engagement of firms in exports. In particular, regional authorities are active in exports' promotion, we evaluate its efficiency, as well as have noticed that export performance reflects regional competitiveness. 
For the time being, the research into exporting activity determinants at the regional level is sparse. In the present study, we decided to combine a two-country perspective which enabled us to formulate more universal conclusions.

The aim of the research was to empirically identify factors which determine the exports of Polish and Spanish NUTS-2 regions. Upon the investigation of data and review of possibilities, we applied a robust method of estimation - namely PCSE-PSAR1 due to the presence of heteroskedasticity and region-specific autoregressive processes. The analysis was conducted jointly for a sample of Polish and Spanish NUTS-2 regions. In addition, we checked the robustness of the results by splitting the sample of the regions into two national subsamples, as well as by adding fixed temporal effect - it did not affect the key results.

The size of regions positively determines their exports (in line with Naudé and Gries (2009) conclusions), which is in line with the home market effect hypothesis. The share of agriculture in total employment has an adverse impact. On the other hand, manufacturing, as expected, in a positive way influences regions' exports. It brings an important policy implication that de-industrialisation could hamper regional export base, however, the increasing tradability of services could at least partially mitigate this effect.

The bordering regions have superiority in the access to foreign markets and this observation is in line with the gravity type model's conclusions. Also, the latitude of the region's capital is important, in fact, it reflects superior climate characteristics. Our results are in line with the observations by Chasco et al. (2012) that more southern latitude adversely affected the extent of economic agglomeration European NUTS-2 regions showed.

FDI turned out to positively impact regions' exports (in line with the results by Ciżkowicz et al., 2013). Nonetheless, a higher magnitude of impact was expected, as at least in the case of Poland's regions - the share of FOEs in the exports of a particular region is high. However, we do not have data for the Spanish regions on the share of FOEs in exports, and therefore information on the number of FOEs was used instead. This aspect of research needs a more profound inquiry into the nature of the FDI inflow into regions, as far as the influence on exports is concerned (the role of large MNEs and the sectoral structure of FDI in particular).

Contrary to the expectations, human capital does not influence exports significantly; neither do business expenditures on R\&D - our proxy for innovation potential. These aspects need further examination and, probably, different ways of the inclusion of human capital and R\&D-related variables into the model. According to the predictions of the heterogeneity concept (new-new trade theory) and empirical research performed at the firm level, these two factors should positively influence exports. The question of the differentiation between an extensive and an intensive margin of exports is supposed to matter. However, as pointed by Johansson and Karlsson (2007), knowledge cannot be 'spatially trapped', which means that inter-regional accessibility to R\&D should be more thoroughly assessed, also with paying attention to margins of exports.

Contrary to our expectations, the impact of maritime transport - which proxies the size of seaports - is negative, so is the size of the regional airport. It deserves further research and probably other ways of the inclusion of transport infrastructure-related variables into the model. The seaport size (and the size of the airport - respectively) generates positive spillovers on exports potential that are not only limited to the particular region in which this kind of infrastructure is located. 
Table 1. Descriptive statistics of utilized variables

\begin{tabular}{|c|c|c|c|c|c|c|c|c|c|}
\hline Variable & Description & Obs & Mean & Std. Dev. & Min & Max & Description & $\begin{array}{c}\text { Expected } \\
\text { sign }\end{array}$ & Factor \\
\hline In_exp_v & N. log of region's export value (M EUR) & 385 & 21.93408 & 2.099095 & 11.2649 & 24.86736 & Izba Celna \& DataComex Español & & Dependent variable \\
\hline In_pop & N. log of region's population & 385 & 7.3962 & 1.034942 & 4.173002 & 9.035941 & QoG Regional dataset & + & Factor conditions/Size \\
\hline agriculture & Employment in agriculture, forestry $\&$ fishing as $\%$ of total & 385 & 5.927273 & 7.192307 & 0 & 29.3 & QoG Regional dataset & - & Market conditions \\
\hline manufacturing & Employment in manufacturing as \% of total & 385 & 10.08571 & 9.309274 & 0 & 26.9 & QoG Regional dataset & + & Market conditions \\
\hline In_gdp_pc & N. log of real GDP per capita in EUR & 340 & 2.903982 & 0.5555303 & 1.808394 & 3.832792 & QoG Regional dataset & + & Market conditions \\
\hline In_area & $\mathrm{N}$. log of area of a region sq km & 385 & 9.407294 & 1.796842 & 2.564949 & 11.45346 & QoG Regional dataset & + & Factor conditions/Size \\
\hline borderegion & Dummy variable - border region & 385 & 0.5428571 & 0.4988081 & 0 & 1 & Own elaboration & + & $\begin{array}{c}\text { Remoteness and } \\
\text { geography }\end{array}$ \\
\hline access_to_sea & Dummy variable - direct access to sea & 385 & 0.3142857 & 0.4648348 & 0 & 1 & Own elaboration & + & $\begin{array}{l}\text { Remoteness and } \\
\text { geography }\end{array}$ \\
\hline metro & $\begin{array}{c}\text { Dummy variable - metropolitan region in accordance with } \\
\text { ESPON MEGA classification (MEGA 1-4) }\end{array}$ & 385 & 0.3714286 & 0.4838154 & 0 & 1 & $\begin{array}{l}\text { Own elaboration based on } \\
\text { EPSON classification }\end{array}$ & + & Spatial agglomeration \\
\hline capital & Dummy variable - capital region & 385 & 0.0571429 & 0.2324174 & 0 & 1 & Own elaboration & + & Spatial agglomeration \\
\hline mega1 & $\begin{array}{c}\text { Dummy variable - metropolitan region MEGA } 1 \text { in accordance } \\
\text { with ESPON classification }\end{array}$ & 385 & 0.0571429 & 0.2324174 & 0 & 1 & $\begin{array}{l}\text { Own elaboration based on } \\
\text { EPSON classification }\end{array}$ & + & Spatial agglomeration \\
\hline mega3 & $\begin{array}{c}\text { Dummy variable - metropolitan region MEGA } 3 \text { in accordance } \\
\text { with ESPON classification }\end{array}$ & 385 & 0.0571429 & 0.2324174 & 0 & 1 & $\begin{array}{l}\text { Own elaboration based on } \\
\text { EPSON classification }\end{array}$ & + & Spatial agglomeration \\
\hline mega4 & $\begin{array}{c}\text { Dummy variable - metropolitan region MEGA } 4 \text { in accordance } \\
\text { with ESPON classification }\end{array}$ & 385 & 0.2571429 & 0.4376275 & 0 & 1 & $\begin{array}{l}\text { Own elaboration based on } \\
\text { EPSON classification }\end{array}$ & + & Spatial agglomeration \\
\hline latitude & Latitude of region's capital city & 385 & 45.30524 & 6.692785 & 28.15 & 54.35 & QoG Regional dataset & $+/-$ & $\begin{array}{c}\text { Remoteness and } \\
\text { geography }\end{array}$ \\
\hline longitude & Longitude of region's capital city & 385 & 6.748095 & 11.89425 & -15.41667 & 23.15 & QoG Regional dataset & $+/-$ & $\begin{array}{l}\text { Remoteness and } \\
\text { geography }\end{array}$ \\
\hline In_no_fdi_cum_za & N. log of cumulated no. of FDI in a region, zero adjusted & 385 & 3.582096 & 3.692235 & -6.907755 & 9.802451 & PAlilZ \& Datalnvex Español & + & FDI \\
\hline tfp & TFP of a region & 340 & 0.5797839 & 0.214931 & 0.2530706 & 1.131817 & $\begin{array}{c}\text { Own elaboration based on } \\
\text { QoG Regional dataset and } \\
\text { PWT } 9.0\end{array}$ & + & Market conditions \\
\hline hc & $\begin{array}{l}\text { Human capital proxy - share of population with tertiary } \\
\text { education in population } 24-65\end{array}$ & 385 & 23.43299 & 10.24693 & 0 & 47.2 & QoG Regional dataset & + & Factor conditions \\
\hline berd & Business Expenditures on R\&D as \% of real GDP of a region & 385 & 0.2786753 & 0.3565416 & 0 & 1.7 & QoG Regional dataset & + & $\begin{array}{c}\text { Technological } \\
\text { knowledge base }\end{array}$ \\
\hline In_transp_rail & N. log of total railway lines $(\mathrm{km})$ & 385 & 3.223167 & 6.046421 & -6.907755 & 7.785721 & QoG Regional dataset & + & Infrastructure \\
\hline $\begin{array}{l}\text { In_transp_motor } \\
\text { way }\end{array}$ & N. log of motorways $(\mathrm{km})$ & 385 & 0.7780959 & 6.19977 & -6.907755 & 7.80873 & QoG Regional dataset & + & Infrastructure \\
\hline In_transp_road & N. log of other roads (kilometre) & 385 & 6.126701 & 6.332717 & -6.907755 & 10.88138 & QoG Regional dataset & + & Infrastructure \\
\hline $\begin{array}{l}\text { In_transp_mariti } \\
\text { me }\end{array}$ & $\begin{array}{l}\text { N. log of maritime transport, freight loaded and unloaded } \\
(1000 \text { 's tonnes) }\end{array}$ & 385 & -1.453063 & 7.872984 & -6.907755 & 11.69182 & QoG Regional dataset & + & Infrastructure \\
\hline In_transp_airport & $\begin{array}{l}\text { N. log of air transport, freight and mail loaded and unloaded (1000's } \\
\text { tonnes) }\end{array}$ & 385 & -3.711337 & 4.572918 & -6.907755 & 6.045008 & QoG Regional dataset & + & Infrastructure \\
\hline
\end{tabular}

Source: own study. 
Table 2. OLS and PCSE-PSAR1 estimates of regional exports model on joint Polish \& Spanish NUTS-2 sample

\begin{tabular}{|c|c|c|c|c|c|c|c|c|c|c|}
\hline Variable & $\begin{array}{c}\text { M1 } \\
\text { pooled OLS }\end{array}$ & $\begin{array}{c}\text { M2 } \\
\text { PCSE-PSAR1 }\end{array}$ & $\begin{array}{c}\text { M3 } \\
\text { pooled OLS }\end{array}$ & $\begin{array}{c}\text { M4 } \\
\text { PCSE-PSAR1 }\end{array}$ & $\begin{array}{c}\text { M5 } \\
\text { pooled OLS }\end{array}$ & $\begin{array}{c}\text { M6 } \\
\text { PCSE-PSAR1 }\end{array}$ & $\begin{array}{c}\text { M7 } \\
\text { pooled OLS }\end{array}$ & $\begin{array}{c}\text { M8 } \\
\text { PCSE-PSAR1 }\end{array}$ & $\begin{array}{c}\text { M9 } \\
\text { pooled OLS }\end{array}$ & $\begin{array}{c}\text { M10 } \\
\text { PCSE-PSAR1 }\end{array}$ \\
\hline In_pop & $\begin{array}{c}0.862^{* * *} \\
(0.111) \\
\end{array}$ & $\begin{array}{c}0.507^{* * *} \\
(0.0864) \\
\end{array}$ & $\begin{array}{c}1.165^{* * *} \\
(0.120)\end{array}$ & $\begin{array}{c}1.194^{* * *} \\
(0.178) \\
\end{array}$ & $\begin{array}{c}0.730^{* * *} \\
(0.129) \\
\end{array}$ & $\begin{array}{c}0.387^{* * *} \\
(0.101) \\
\end{array}$ & $\begin{array}{c}0.761^{* * *} \\
(0.127) \\
\end{array}$ & $\begin{array}{c}0.527^{* * *} \\
(0.147) \\
\end{array}$ & $\begin{array}{c}0.823 * * * \\
(0.1078)\end{array}$ & $\begin{array}{c}0.498^{* * *} \\
(0.0834)\end{array}$ \\
\hline agriculture & $\begin{array}{c}-0.0401^{* * *} \\
(0.00898)\end{array}$ & $\begin{array}{c}-0.0127^{*} \\
(0.00663) \\
\end{array}$ & $\begin{array}{c}-0.0372 * * * \\
(0.00845)\end{array}$ & $\begin{array}{c}-0.0139 * * \\
(0.00632) \\
\end{array}$ & $\begin{array}{c}-0.0409 * * * \\
(0.00895)\end{array}$ & $\begin{array}{c}-0.0172^{* * *} \\
(0.00574)\end{array}$ & $\begin{array}{c}-0.0406^{* * *} \\
(0.00899)\end{array}$ & $\begin{array}{c}-0.0138^{*} \\
(0.00703) \\
\end{array}$ & $\begin{array}{c}-0.0295^{* * *} \\
(0.00896)\end{array}$ & $\begin{array}{c}-0.0128 \\
(0.00844)\end{array}$ \\
\hline manufacturing & $\begin{array}{c}0.0517^{* * *} \\
(0.00664)\end{array}$ & $\begin{array}{c}0.00903 \\
(0.00691) \\
\end{array}$ & $\begin{array}{c}0.0293^{* * *} \\
(0.00641)\end{array}$ & $\begin{array}{c}0.00352 \\
(0.00663) \\
\end{array}$ & $\begin{array}{c}0.0480^{* * *} \\
(0.00686)\end{array}$ & $\begin{array}{c}0.00934 \\
(0.00600) \\
\end{array}$ & $\begin{array}{c}0.0532^{* * *} \\
(0.00665)\end{array}$ & $\begin{array}{c}0.0102 \\
(0.00701)\end{array}$ & $\begin{array}{c}0.0481 * * * \\
(0.00643)\end{array}$ & $\begin{array}{c}0.0125 \\
(0.00817) \\
\end{array}$ \\
\hline In_gdp_pc & $\begin{array}{c}0.450^{* * *} \\
(0.0923) \\
\end{array}$ & $\begin{array}{l}0.650^{* * *} \\
(0.0940) \\
\end{array}$ & $\begin{array}{c}1.514^{* * *} \\
(0.159) \\
\end{array}$ & $\begin{array}{c}1.145^{* * *} \\
(0.293) \\
\end{array}$ & $\begin{array}{l}0.256^{*} \\
(0.133) \\
\end{array}$ & $\begin{array}{c}0.421^{* * *} \\
(0.134) \\
\end{array}$ & $\begin{array}{c}0.380^{* * *} \\
(0.0981) \\
\end{array}$ & $\begin{array}{c}0.630^{* * *} \\
(0.115) \\
\end{array}$ & & \\
\hline In_area & $\begin{array}{c}0.537^{* * *} \\
(0.0528) \\
\end{array}$ & $\begin{array}{c}0.776^{* * *} \\
(0.149) \\
\end{array}$ & $\begin{array}{c}0.372^{* * *} \\
(0.0609)\end{array}$ & $\begin{array}{c}0.416 * * * \\
(0.0960) \\
\end{array}$ & $\begin{array}{c}0.514^{* * *} \\
(0.0537)\end{array}$ & $\begin{array}{c}0.734^{* * *} \\
(0.154) \\
\end{array}$ & $\begin{array}{c}0.570^{* * *} \\
(0.0577) \\
\end{array}$ & $\begin{array}{c}0.767^{* * *} \\
(0.140) \\
\end{array}$ & $\begin{array}{c}0.547^{* * *} \\
(0.0511) \\
\end{array}$ & $\begin{array}{c}0.765^{* * *} \\
(0.142)\end{array}$ \\
\hline borderegion & $\begin{array}{c}0.139 \\
(0.0961) \\
\end{array}$ & $\begin{array}{c}0.169 * * * \\
(0.0441) \\
\end{array}$ & $\begin{array}{c}0.169^{*} \\
(0.0863) \\
\end{array}$ & $\begin{array}{c}0.336 * * * \\
(0.0864) \\
\end{array}$ & $\begin{array}{c}0.158 \\
(0.0962) \\
\end{array}$ & $\begin{array}{c}0.178 * * * \\
(0.0652) \\
\end{array}$ & $\begin{array}{l}0.176^{*} \\
(0.103) \\
\end{array}$ & $\begin{array}{l}0.169 * * \\
(0.0724) \\
\end{array}$ & $\begin{array}{c}0.1418 \\
(0.0919) \\
\end{array}$ & $\begin{array}{c}0.127^{* * *} \\
(0.0291) \\
\end{array}$ \\
\hline access_to_sea & $\begin{array}{c}0.227^{* *} \\
(0.100) \\
\end{array}$ & $\begin{array}{c}0.190^{* * *} \\
(0.0611) \\
\end{array}$ & $\begin{array}{c}0.269 * * * \\
(0.0962) \\
\end{array}$ & $\begin{array}{c}0.0795 \\
(0.0853) \\
\end{array}$ & $\begin{array}{c}0.211^{* *} \\
(0.100) \\
\end{array}$ & $\begin{array}{l}0.154^{* *} \\
(0.0710) \\
\end{array}$ & $\begin{array}{c}0.322^{* * *} \\
(0.107) \\
\end{array}$ & $\begin{array}{c}0.310^{* * *} \\
(0.0759) \\
\end{array}$ & $\begin{array}{c}0.2686^{* * *} \\
(0.0962) \\
\end{array}$ & $\begin{array}{c}0.333^{* * *} \\
(0.0623) \\
\end{array}$ \\
\hline metro & $\begin{array}{l}0.383^{* *} \\
(0.155) \\
\end{array}$ & $\begin{array}{c}0.790^{* * *} \\
(0.101) \\
\end{array}$ & $\begin{array}{l}-0.217 \\
(0.155) \\
\end{array}$ & $\begin{array}{c}0.102 \\
(0.208) \\
\end{array}$ & $\begin{array}{c}0.433^{* * *} \\
(0.156) \\
\end{array}$ & $\begin{array}{c}0.753^{* * *} \\
(0.104) \\
\end{array}$ & & & $\begin{array}{c}0.3715^{* *} \\
(0.1492) \\
\end{array}$ & $\begin{array}{c}0.767^{* * *} \\
(0.118) \\
\end{array}$ \\
\hline latitude & & & $\begin{array}{c}0.105^{* * *} \\
(0.0225) \\
\end{array}$ & $\begin{array}{c}0.164^{* * *} \\
(0.0257) \\
\end{array}$ & & & & & & \\
\hline longitude & & & $\begin{array}{l}0.00553 \\
(0.0150) \\
\end{array}$ & $\begin{array}{c}-0.0496 * \\
(0.0272) \\
\end{array}$ & & & & & & \\
\hline In_no_fdi_cum_za & & & & & $\begin{array}{c}0.0556 * * \\
(0.0278) \\
\end{array}$ & $\begin{array}{c}0.0734 * * * \\
(0.0212) \\
\end{array}$ & & & & \\
\hline mega1 & & & & & & & $\begin{array}{c}0.477 \\
(0.342) \\
\end{array}$ & $\begin{array}{c}0.741^{* *} \\
(0.340) \\
\end{array}$ & & \\
\hline mega3 & & & & & & & $\begin{array}{c}0.238 \\
(0.284) \\
\end{array}$ & $\begin{array}{c}0.379 \\
(0.295) \\
\end{array}$ & & \\
\hline mega4 & & & & & & & $\begin{array}{c}0.366^{* *} \\
(0.159)\end{array}$ & $\begin{array}{c}0.721^{* * *} \\
(0.130)\end{array}$ & & \\
\hline capital & & & & & & & $\begin{array}{c}0.613^{* *} \\
(0.270)\end{array}$ & $\begin{array}{c}0.438^{* * *} \\
(0.0879)\end{array}$ & & \\
\hline tfp & & & & & & & & & $\begin{array}{c}1.566^{* * * *} \\
(0.2317)\end{array}$ & $\begin{array}{c}1.081^{* * * *} \\
(0.329)\end{array}$ \\
\hline constant & $\begin{array}{c}8.546^{* * * *} \\
(0.492)\end{array}$ & $\begin{array}{c}8.557^{* * *} \\
(1.248)\end{array}$ & $\begin{array}{c}0.381 \\
(1.189)\end{array}$ & $\begin{array}{l}-1.476 \\
(2.339) \\
\end{array}$ & $\begin{array}{c}10.13^{* * * *} \\
(0.932)\end{array}$ & $\begin{array}{c}10.33^{* * * *} \\
(1.188)\end{array}$ & $\begin{array}{c}9.100 * * * \\
(0.587)\end{array}$ & $\begin{array}{c}8.559 * * * \\
(1.601)\end{array}$ & $\begin{array}{c}9.096^{* * *} \\
(0.423)\end{array}$ & $\begin{array}{c}9.897^{* * * *} \\
(1.379)\end{array}$ \\
\hline $\begin{array}{l}\text { Observations } \\
\text { R-squared } \\
\text { Number of reg_id }\end{array}$ & $\begin{array}{c}340 \\
0.873\end{array}$ & $\begin{array}{c}340 \\
0.993 \\
34\end{array}$ & $\begin{array}{c}340 \\
0.899\end{array}$ & $\begin{array}{c}340 \\
0.994 \\
34\end{array}$ & $\begin{array}{c}340 \\
0.874\end{array}$ & $\begin{array}{c}340 \\
0.994 \\
34\end{array}$ & $\begin{array}{c}340 \\
0.876\end{array}$ & $\begin{array}{c}340 \\
0.993 \\
34\end{array}$ & $\begin{array}{c}340 \\
0.880\end{array}$ & $\begin{array}{c}340 \\
0.993 \\
34\end{array}$ \\
\hline
\end{tabular}

PCSE-PSAR1 - Prais-Winsten regression, correlated panels corrected standard errors (PCSEs). Standard errors in parentheses $* * * p<0.01, * * p<0.05, * p<0.1$.

Source: own elaboration in STATA 14. 
Table 2. continued

\begin{tabular}{|c|c|c|c|c|c|c|}
\hline Variable & $\begin{array}{c}\text { M11 } \\
\text { pooled OLS }\end{array}$ & $\begin{array}{c}\text { M12 } \\
\text { PCSE-PSAR1 }\end{array}$ & $\begin{array}{c}\text { M13 } \\
\text { pooled OLS }\end{array}$ & $\begin{array}{c}\text { M14 } \\
\text { PCSE-PSAR1 }\end{array}$ & $\begin{array}{c}\text { M15 } \\
\text { pooled OLS }\end{array}$ & $\begin{array}{c}\text { M16 } \\
\text { PCSE-PSAR1 }\end{array}$ \\
\hline In_pop & $\begin{array}{c}0.832^{* * *} \\
(0.101) \\
\end{array}$ & $\begin{array}{c}1.510^{* * *} \\
(0.165) \\
\end{array}$ & $\begin{array}{c}0.955^{* * *} \\
(0.113) \\
\end{array}$ & $\begin{array}{c}0.470^{* * *} \\
(0.139) \\
\end{array}$ & $\begin{array}{c}0.956^{* * *} \\
(0.115) \\
\end{array}$ & $\begin{array}{c}0.489 * * * \\
(0.119) \\
\end{array}$ \\
\hline agriculture & $\begin{array}{c}-0.0421^{* * *} \\
(0.00834)\end{array}$ & $\begin{array}{c}6.42 \mathrm{e}-05 \\
(0.00631)\end{array}$ & $\begin{array}{c}-0.0327^{* * *} \\
(0.00849)\end{array}$ & $\begin{array}{c}-0.00848 \\
(0.00646)\end{array}$ & $\begin{array}{c}-0.0373^{* * *} \\
(0.00851)\end{array}$ & $\begin{array}{c}-0.0122^{*} \\
(0.00740)\end{array}$ \\
\hline manufacturing & $\begin{array}{c}0.0436^{* * *} \\
(0.00653) \\
\end{array}$ & $\begin{array}{c}0.00426 \\
(0.00544) \\
\end{array}$ & $\begin{array}{c}0.0389 * * * \\
(0.00642) \\
\end{array}$ & $\begin{array}{c}0.00817 \\
(0.00645) \\
\end{array}$ & $\begin{array}{c}0.0425^{* * *} \\
(0.00643) \\
\end{array}$ & $\begin{array}{c}0.0100 \\
(0.00712) \\
\end{array}$ \\
\hline In_gdp_pc & & & $\begin{array}{c}0.390^{* * *} \\
(0.121)\end{array}$ & $\begin{array}{c}0.435^{* * *} \\
(0.0999) \\
\end{array}$ & $\begin{array}{c}0.410^{* * *} \\
(0.122) \\
\end{array}$ & $\begin{array}{c}0.543^{* * *} \\
(0.0980) \\
\end{array}$ \\
\hline In_area & $\begin{array}{c}0.522^{* * *} \\
(0.0483) \\
\end{array}$ & $\begin{array}{c}0.305^{* *} \\
(0.134) \\
\end{array}$ & $\begin{array}{c}0.339^{* * *} \\
(0.0577) \\
\end{array}$ & $\begin{array}{c}0.662^{* * *} \\
(0.125) \\
\end{array}$ & $\begin{array}{c}0.374^{* * *} \\
(0.0576) \\
\end{array}$ & $\begin{array}{c}0.679 * * * \\
(0.120)\end{array}$ \\
\hline borderegion & $\begin{array}{c}-0.0208 \\
(0.0887)\end{array}$ & $\begin{array}{l}-0.0635 \\
(0.0503)\end{array}$ & $\begin{array}{c}0.0738 \\
(0.0897)\end{array}$ & $\begin{array}{l}0.182^{* *} \\
(0.0741)\end{array}$ & $\begin{array}{c}0.0990 \\
(0.0908)\end{array}$ & $\begin{array}{c}0.163^{* * *} \\
(0.0606)\end{array}$ \\
\hline access_to_sea & $\begin{array}{c}0.322^{* * *} \\
(0.0910) \\
\end{array}$ & $\begin{array}{c}0.758^{* * *} \\
(0.107) \\
\end{array}$ & $\begin{array}{c}0.579 * * * \\
(0.172) \\
\end{array}$ & $\begin{array}{c}0.589 * * * \\
(0.108) \\
\end{array}$ & & \\
\hline metro & $\begin{array}{c}0.289^{* *} \\
(0.136) \\
\end{array}$ & $\begin{array}{l}0.0820 \\
(0.108) \\
\end{array}$ & $\begin{array}{c}0.103 \\
(0.150) \\
\end{array}$ & $\begin{array}{c}0.764^{* * *} \\
(0.210) \\
\end{array}$ & $\begin{array}{c}0.165 \\
(0.151) \\
\end{array}$ & $\begin{array}{c}0.911^{* * *} \\
(0.184) \\
\end{array}$ \\
\hline hc & $\begin{array}{c}-0.00840 \\
(0.00549)\end{array}$ & $\begin{array}{c}-0.00438 \\
(0.00471)\end{array}$ & & & & \\
\hline berd & $\begin{array}{c}0.967^{* * *} \\
(0.158) \\
\end{array}$ & $\begin{array}{l}0.0127 \\
(0.134) \\
\end{array}$ & & & & \\
\hline In_transp_rail & & & $\begin{array}{c}0.107^{* * *} \\
(0.0212) \\
\end{array}$ & $\begin{array}{l}0.0445^{*} \\
(0.0263) \\
\end{array}$ & $\begin{array}{c}0.140^{* * *} \\
(0.0191) \\
\end{array}$ & $\begin{array}{c}0.0588^{* *} \\
(0.0291) \\
\end{array}$ \\
\hline In_transp_motorway & & & $\begin{array}{l}0.0204^{*} \\
(0.0115) \\
\end{array}$ & $\begin{array}{c}0.0155^{*} \\
(0.00940)\end{array}$ & $\begin{array}{c}0.0106 \\
(0.0113) \\
\end{array}$ & $\begin{array}{c}0.0125 \\
(0.00952)\end{array}$ \\
\hline In_transp_road & & & $\begin{array}{c}-0.100^{* * *} \\
(0.0219) \\
\end{array}$ & $\begin{array}{l}-0.0461 \\
(0.0303) \\
\end{array}$ & $\begin{array}{c}-0.129 * * * \\
(0.0204) \\
\end{array}$ & $\begin{array}{c}-0.0571^{*} \\
(0.0328) \\
\end{array}$ \\
\hline In_transp_maritime & & & $\begin{array}{c}-0.0346^{* * *} \\
(0.0112) \\
\end{array}$ & $\begin{array}{c}-0.0163^{* *} \\
(0.00815) \\
\end{array}$ & $\begin{array}{c}-0.00294 \\
(0.00615) \\
\end{array}$ & $\begin{array}{c}-0.00722 \\
(0.00514) \\
\end{array}$ \\
\hline In_transp_airport & & & $\begin{array}{l}0.0260^{*} \\
(0.0146)\end{array}$ & $\begin{array}{l}0.00593 \\
(0.0117) \\
\end{array}$ & $\begin{array}{c}0.0143 \\
(0.0144) \\
\end{array}$ & $\begin{array}{c}-1.57 \mathrm{e}-07 \\
(0.0113) \\
\end{array}$ \\
\hline constant & $\begin{array}{c}10.41^{* * *} \\
(0.409) \\
\end{array}$ & $\begin{array}{c}7.374^{* * *} \\
(1.705) \\
\end{array}$ & $\begin{array}{c}10.34^{* * *} \\
(0.749) \\
\end{array}$ & $\begin{array}{c}10.49 * * * \\
(1.197) \\
\end{array}$ & $\begin{array}{c}10.16^{* * *} \\
(0.758) \\
\end{array}$ & $\begin{array}{c}10.02^{* * *} \\
(1.242) \\
\end{array}$ \\
\hline $\begin{array}{r}\text { Observations } \\
\text { R-squared } \\
\text { Number of reg_id }\end{array}$ & $\begin{array}{c}385 \\
0.869\end{array}$ & $\begin{array}{c}385 \\
0.995 \\
35\end{array}$ & $\begin{array}{c}340 \\
0.895\end{array}$ & $\begin{array}{c}340 \\
0.993 \\
34\end{array}$ & $\begin{array}{c}340 \\
0.891\end{array}$ & $\begin{array}{c}340 \\
0.993 \\
34\end{array}$ \\
\hline
\end{tabular}

PCSE-PSAR1 - Prais-Winsten regression, correlated panels corrected standard errors (PCSEs). Standard errors in parentheses $* * * p<0.01,{ }^{* *} p<0.05, * p<0.1$. Source: own elaboration in STATA 14. 
The utilized approach has its limits due to the nature of the estimated model and due to the utilized econometric methodology. We deal with the aggregated data flows. The choice of the variables was restricted by data availability. The presented research will be supplemented in a number of articles verifying the determinants of bilateral trade in a region-country framework using the gravity approach, as well as an article identifying the factors affecting the intensity and structure of intra-industry trade in the region-country framework. Furthermore, we do not account for the global value chains as the analysis was conducted at the aggregated level (regional exports) and we do not take into account the regional value added.

The future research should try to extend the sample of regions considered in the analysis by incorporating other countries, as well as take into account the impact of intracountry, interregional trade flows in order to test the robustness of the obtained results further. In addition, an analysis can be conducted for regional exports by sector in order to identify potential sectoral differences.

\section{REFERENCES}

Andersson, M., \& Johansson, S. (2010). Human capital and the structure of regional export flows. Technology in Society, 32(3), 230-240.

Becchetti, L., Panizza, A. de, \& Oropallo, F. (2007). Role of Industrial District Externalities in Export and Value-added Performance: Evidence from the Population of Italian Firms. Regional Studies, 41(5), 601-621. https://doi.org/10.1080/00343400701281691

Beck, N., \& Katz, J.N. (1995). What To Do (and Not to Do) with Time-Series Cross-Section Data. American Political Science Review, 89(03), 634-647. https://doi.org/10.2307/2082979

Bensassi, S., Márquez-Ramos, L., Martínez-Zarzoso, I., \& Suárez-Burguet, C. (2015). Relationship between logistics infrastructure and trade: Evidence from Spanish regional exports. Transportation Research Part A: Policy and Practice, 72, 47-61. https://doi.org/10.1016/j.tra.2014.11.007

Berube, A., \& Parilla, J. (2012). Metro Trade. Cities Return to their Roots in the Global Economy. Washington: The Brookings Institution.

Beugelsdijk, S., Klasing, M.J., \& Milionis, P. (2017). Regional economic development in Europe: the role of total factor productivity. Regional Studies, 52(4), 1-16. https://doi.org/10.1080/00343404.2017.1334118

Brakman, S., \& van Marrewijk, C. (2013). Lumpy countries, urbanization, and trade. Journal of International Economics, 89(1), 252-261. https://doi.org/10.1016/j.jinteco.2012.05.004

Boschma, R. (2005). Proximity and Innovation: A Critical Assessment. Regional Studies, 39(1), 61-74. https://doi.org/10.1080/0034340052000320887

Boschma, R., \& Frenken, K. (2011). The emerging empirics of evolutionary economic geography. Journal of Economic Geography, 11(2), 295-307. https://doi.org/10.1093/jeg/lbq053

Brodzicki, T., \& Umiński, S. (2018). A gravity panel data analysis of foreign trade by regions: The role of metropolises and history. Regional Studies, 52(2), 261-273. https://doi.org/10.1080/00343404.2017.1296123

Cassey, A.J. (2011). State foreign export patterns. Southern Economic Journal, 78(2), 308-329. https://doi.org/10.4284/0038-4038-78.2.308

Charron, N., Dahlberg, S., Holmberg, S., Rothstein, B., Khomenko, A., \& Svensson, R. (2016). The Quality of Government EU Regional Dataset (version Sep16). Gothenburg, University of Gothenburg: The Quality of Government Institute. 
Chasco, C., Lopez, A., \& Guillain, R. (2012). The Influence of Geography on the Spatial Agglomeration of Production in the European Union. Spatial Economic Analysis, 7(2), 247-263. https://doi.org/10.1080/17421772.2012.669490

Cieślik, A. (2017a). Determinanty bezpośrednich inwestycji zagranicznych w Polsce: Czy integracja europejska ma znaczenie?. Collegium of Economic Analysis Annals, (47), 65-82.

Cieślik, A. (2017b). Determinants of MNE Activity in Poland: The Case of Firms from EU-15. Entrepreneurial Business and Economics Review, 5(1), 151. https://doi.org/10.15678/EBER.2017.050109

Ciołek, D., \& Brodzicki, T. (2016). Determinanty produktywności polskich powiatów. Bank i Kre$d y t, 47(5), 463-494$.

Ciżkowicz, P., Rzońca, A., \& Umiński, S. (2013). The determinants of regional exports in Poland - a panel data analysis. Post-Communist Economies, 25(2), 206-224. https://doi.org/10.1080/14631377.2013.787741

Courant, P.N., \& Deardorff, A.V. (1992). International Trade with Lumpy Countries. Journal of Political Economy, 100(1), 198-210 https://doi.org/10.1086/261813

Dühr, S. (2005). Potentials for polycentric development in Europe: The ESPON 1.1.1 project report. Planning Practice and Research, 20(2), 235-239. https://doi.org /10.1080/02697450500414728

Dunning, J.H., \& Lundan, S.M. (2008). Multinational enterprises and the global economy (2nd ed.). Cheltenham, UK, Northampton, MA: Edward Elgar.

Duranton, G., \& Puga, D. (2004). Micro-foundations of urban agglomeration economies. In J.V. Henderson \& J.F. Thisse (Eds.), Handbook of Regional and Urban Economics, 4 (pp. $2063-$ 2117). Cities and Geography Elsevier.

Easterly, W., \& Levine, R. (2001). What have we learned from a decade of empirical research on growth? It's not factor accumulation: Stylized facts and growth Models. The World Bank Economic Review, 15(2), 177-219. https://doi.org/10.1093/wber/15.2.177

Estrin, S., Meyer, K.E., Wright, M., \& Foliano, F. (2008). Export propensity and intensity of subsidiaries in emerging economies. International Business Review, 17(5), 574-586. https://doi.org/10.1016/j.ibusrev.2008.04.002

Feenstra, R.C., Inklaar, R., \& Timmer, M.P. (2015). The Next Generation of the Penn World Table. American Economic Review, 105(10), 3150-3182. https://doi.org/10.1257/aer.20130954

Forsgren, M. (2008). Theories of the Multinational Firm: A Multidimensional Creature in the Global Economy. Cheltenham, UK, Northampton, MA, USA: Edward Elgar.

Gradzewicz, M., \& Kolasa, M. (2005). Napływ bezpośrednich inwestycji zagranicznych a wzrost gospodarczy w Polsce. Ekonomista, (4), 515-527.

Guerrieri, P., \& lammarino, S. (2006). Euro-Commentary: The Rise Of 'Many Mezzogiorni' European Urban and Regional Studies, 13(2), 167-178. https://doi.org/10.1177/0969776406060829

Ha, S.J., \& Swales, J.K. (2012). The export-base model with a supply-side stimulus to the export sector. The Annals of Regional Science, 49(2), 323-353. https://doi.org/10.1007/s00168-010-0423-3

Johansson, S., \& Karlsson, C. (2007). R\&D accessibility and regional export diversity. The Annals of Regional Science, 41(3), 501-523. https://doi.org/10.1007/s00168-007-0122-x

Kolasa, M. (2008). How does FDI inflow affect productivity of domestic firms? The role of horizontal and vertical spillovers, absorptive capacity and competition. The Journal of International Trade \& Economic Development, 17(1), 155-173. https://doi.org/10.1080/09638190701728131

Márquez-Ramos, L. (2016a). The Role of Institutional Environment in International Trade. The Case of Spanish Regions. REGION, 3(2), 125. https://doi.org/10.18335/region.v3i2.147

Márquez-Ramos, L. (2016b). Port facilities, regional spillovers and exports: Empirical evidence from Spain. Papers in Regional Science, 95(2), 329-351. https://doi.org/10.1111/pirs.12127 
Matthee, M., \& Naudé, W. (2008). The Determinants of Regional Manufactured Exports from a Developing Country. International Regional Science Review, 31(4), 343-358. https://doi.org/10.1177\%2F0160017608319413

Mayer, T., \& Ottaviano, G.I.P. (2008). The Happy Few: The Internationalisation of European Firms. Intereconomics, 43(3), 135-148. https://doi.org/10.1007/s10272-008-0247-x

Melitz, M.J. (2003). The Impact of Trade on Intra-Industry Reallocations and Aggregate Industry Productivity. Econometrica, 71(6), 1695-1725. https://doi.org/10.1111/1468-0262.00467

Naudé, W., \& Gries, T. (2009). Explaining Regional Export Performance in a Developing Country: The Role of Geography and Relative Factor Endowments. Regional Studies, 43(7), 967-979. https://doi.org/10.1080/00343400801932300

Nicolini, R. (2003). On the Determinants of Regional Trade Flows. International Regional Science Review, 26(4), 447-465. https://doi.org/10.1177/0160017603259181

North, D.C. (1955). Location Theory and Regional Economic Growth. Journal of Political Economy, 63(3), 243-258. https://doi.org/10.1086/257668

Ottaviano, G.I.P. (2011). 'New' new economic geography: Firm heterogeneity and agglomeration economies. Journal of Economic Geography, 11(2), 231-240. https://doi.org/10.1093/jeg/lbq041

Parr, J.B., Hewings, G.J.D., Sohn, J., \& Nazara, S. (2002). Agglomeration and Trade: Some Additional Perspectives. Regional Studies, 36(6), 675-684. https://doi.org/10.1068/b35038

Pradhan, J.P., \& Das, K. (2015). Regional export advantage of rising power SMEs. Critical perspectives on International Business, 11(3/4), 236-258. https://doi.org/10.1108/cpoib-10-2013-0040

Pradhan, J.P., \& Zohair, M. (2016). Subnational Export Performance and Determinants. Review of Market Integration, 7(2), 133-174. https://doi.org/10.1177/0974929216653631

Rodriguez, X.A., \& Pallas, J. (2008). Determinants of foreign direct investment in Spain. Applied Economics, 40(19), 2443-2450.

Simmie, J. (2002). Trading Places: Competitive Cities in the Global Economy. European Planning Studies, 10(2), 201-214. https://doi.org/10.1080/09654310120114490

Simmie, J. (2003). Innovation and Urban Regions as National and International Nodes for the Transfer and Sharing of Knowledge. Regional Studies, 37(6-7), 607-620. https://doi.org/10.1080/0034340032000108714

Sirkin, G. (1959). The Theory of the Regional Economic Base. The Review of Economics and Statistics, 41(4), 426-429.

Sun, H. (2001). Foreign Direct Investment and Regional Export Performance in China. Journal of Regional Science, 41(2), 317-336.

Umiński, S. (2016). The regionalisation of commercial policy and of export-related analyses. In K. Gawlikowska-Hueckel \& S. Umiński (Eds.), An analysis of Poland's foreign trade in the light of the latest theoretical concepts. Implications for economic policy at a time of crisis (pp. 212-231). Warsaw: Scholar Publishing House.

Wahl, F. (2016). Does medieval trade still matter? Historical trade centers, agglomeration and contemporary economic development. Regional Science and Urban Economics, 60, 50-60.

Villaverde, J., \& Maza, A. (2012). Foreign direct investment in Spain: Regional distribution and determinants. International Business Review, 21(4), 722-733. https://doi.org/10.1016/j.ibusrev.2011.08.004 


\section{Authors}

Contribution share of authors is equal to T. Brodzicki $-40 \%$, L. Márquez-Ramos - $20 \%$ and S. Umiński $-40 \%$.

\section{Tomasz Brodzicki}

Assistant Professor, University of Gdańsk, Faculty of Economics, Economics of European Integration Division and a Research Partner in the Institute for Development, Sopot, Poland.

Correspondence to: dr hab. Tomasz Brodzicki, University of Gdańsk, Economics of European Integration Division, ul. Armii Krajowej 119/121, 81-824 Sopot, Poland, e-mail: t.brodzicki@ug.edu.pl

\section{Laura Márquez-Ramos}

Senior Research Fellow, University of Adelaide, Institute for International Trade, Adelaide, Australia. Correspondence to: laura.marquez-ramos@adelaide.edu.au

\section{Stanisław Umiński}

Associate Professor of the University of Gdańsk (Research Centre on European Integration) and the vice chairman of Institute for Development in Sopot, Poland.

Correspondence to: prof. UG, dr hab. Stanisław Umiński, University of Gdańsk, Research Centre on European Integration, ul. Armii Krajowej 119/121, 81-824 Sopot or Instytut Rozwoju, ul. J. Czyżewskiego 6/1, 81-706 Sopot, Poland, e-mail:uminski@univ.gda.pl and s.uminski@instytut-rozwoju.org

\section{Acknowledgements and Financial Disclosure}

The research is a part of the project "Regional exporting activity. Assessment of determinants in light of contemporary foreign trade theory for Poland and Spain" financed by the National Science Centre of Poland within the grant no. 2015/19/B/HS4/01704.

\section{Copyright and License}

This article is published under the terms of the Creative Commons

Attribution - NoDerivs (CC BY-ND 4.0) License http://creativecommons.org/licenses/by-nd/4.0/

Published by the Centre for Strategic and International Entrepreneurship - Krakow, Poland 
